SHS Web of Conferences 10, 00010 (2014)

DOI: $10.1051 /$ shsconf $/ 20141000010$

C Owned by the authors, published by EDP Sciences, 2014

\title{
Overall human values in context of institute of criminal procedural compulsory measures
}

\section{J. Groma}

Rīga Stradinšs University, Latvia

\begin{abstract}
International relationships, taking place along with integration and globalization processes, create optimal conditions for sharing and accumulating experience related to fundamental liberties of a human being. Moreover, during the last two decades all over the world human rights are in the focus of interest for specialists practicing in the area of political philosophy and international law. Human rights are deeply interacting with people's social life and public relations. These rights create a powerful basis for relations established between human beings, which include ordering of people relationships, coordination of their behaviour regarding normal functioning of state and society. The person's rights to life, liberty, honour, dignity, violability, conscience, private life and others are tightly connected with people's life in a modern society. Undoubtedly, the above mentioned fundamental rights should be adopted and ensured by the state. Analysis of international and national legal acts declaring fundamental human rights as the major values, from one hand, and Criminal Procedure Law regulating application of criminal procedural compulsory measures, from the other hand, suggests that, undoubtedly, protection of overall human values gets the highest topicality in our days.
\end{abstract}

\section{Introduction}

Many types of sciences including psychology and history involve values in their inquiries, and there are various types of value sciences - aesthetics, ethics and religion (McGregor, 2011). Axiology as a value science stands alone because the other sciences depend upon it (Bahm, 1993). Inquiry on human values and people's choice of basic fundamental values enables people to identify the internal valuing systems that influence their perceptions, decisions and actions.

Legal axiology, is one of the most important divisions of law, since it is the branch of law philosophy that addresses the problem of legal values, explaining in its turn what are the values that will correct a model law. The existence of axiology of law is significant because it shows the role that value within the legal system. A number of international legal norms distinguished as international, European and national declarations, Conventions and Constitution guarantee and regulate human rights, protected by the rule of law. Criminal Procedure Law, in turn, determines the order of criminal procedure that ensures the effective application of the norms of the Criminal Law and the fair regulation of criminal legal relations without unjustified intervention in the life of a person. The goal of the present study is analysis of overall human values in context of institute of criminal procedural compulsory measures.

This is an Open Access article distributed under the terms of the Creative Commons Attribution License 4.0, which permits unrestricted use, distribution, and reproduction in any medium, provided the original work is properly cited. 


\section{Materials and methods}

The sources included the international and national legal acts presented as the followings: The Universal Declaration of Human Rights (UDHR), the European Convention on Human Rights (ECHR), the Constitution of the Republic of Latvia, the Criminal Procedure Law. These sources illustrate the content and interpretation of the analysed human rights. Among the sources analysed, there were also books devoted to the description and analysis of human rights, and scientific publications, which deal with theoretical aspects of criminal procedural regulation of compulsory measures including proportional restriction of human rights and freedoms in criminal procedure.

Several research methods were used in the paper, but the dominant one was the descriptive method, often supplemented with interpretative method. It was used to analyse the relevant international and national legal acts as well as scientific books and periodical publications related to the given study. Finally, the inductive method was used to draw general conclusions appearing from the study.

\section{Results}

As it has been stated in the $U D H R$, all human beings are born free and equal in dignity and rights. Everyone has the right to life, liberty and security of person. No one shall be subjected to arbitrary arrest, detention or exile (UDHR, 1948). The Declaration represents the universal recognition that basic rights and fundamental freedoms are inherent to all human beings. The UDHR has inspired more than 80 international human rights treaties and declarations, a great number of regional human rights conventions, domestic human rights bills, and constitutional provisions, which together constitute a comprehensive legally binding system for the promotion and protection of human rights.

In the recent years, developing the democracy in Latvia, following the huge social-economic reforms, taking place in the state, the Latvian legislator is looking forward to enforce the European guarantees on protection of human rights. The Chapter VIII of the Constitution of the Republic of Latvia declares fundamental human rights. The Article 89 of the Constitution determines that the State shall recognise and protect fundamental human rights in accordance with this Constitution, laws and international agreements binding upon Latvia. Everyone shall be presumed innocent until his or her guilt has been established in accordance with law. Everyone, where his or her rights are violated without basis, has a right to commensurate compensation. Everyone has a right to the assistance of counsel (Article 92). Everyone has the right to liberty and security of person. No one may be deprived of or have their liberty restricted, otherwise than in accordance with law (Article 94). Following this, it must be noted that the right of liberty is of primary importance in a democratic society, but in some cases the competent State institutions ought to take measures for limiting that right of the individual, in order to protect from further offenses and to guarantee security of the other members of the society. Criminal Procedure belongs to the sphere of state action where human rights are considered the most strongly.

World-wide ECHR is an outstanding document in a number of respects. It is the most successful document of international human rights protection, and an innovative instrument as it provided for the first time in the history of international law the possibility for a citizen to sue its own country before a court that had unconditional jurisdiction. Today it is an instrument that has a large influence through the jurisprudence of the European Court of Human Rights on the respect of fundamental rights by the member states of the Council of Europe.

Limitations of the rights of the individuals are explicitly put forward in the wording of Article 5 (Right to liberty and security) of the ECHR:

1. Everyone has the right to liberty and security of person. No one shall be deprived of his liberty save in the following cases and in accordance with a procedure prescribed by law:

a. the lawful detention of a person after conviction by a competent court; 


\section{Int. Conf. SOCIETY. HEALTH. WELFARE.}

b. the lawful arrest or detention of a person for non- compliance with the lawful order of a court or in order to secure the fulfilment of any obligation prescribed by law;

c. the lawful arrest or detention of a person effected for the purpose of bringing him before the competent legal authority on reasonable suspicion of having committed an offence or when it is reasonably considered necessary to prevent his committing an offence or fleeing after having done so;

d. the detention of a minor by lawful order for the purpose of educational supervision or his lawful detention for the purpose of bringing him before the competent legal authority;

e. the lawful detention of persons for the prevention of the spreading of infectious diseases, of persons of unsound mind, alcoholics or drug addicts or vagrants;

f. the lawful arrest or detention of a person to prevent his effecting an unauthorized entry into the country or of a person against whom action is being taken with a view to deportation or extradition.

2. Everyone who is arrested shall be informed promptly, in a language which he understands, of the reasons for his arrest and of any charge against him.

3. Everyone arrested or detained in accordance with the provisions of paragraph 1.c of this article shall be brought promptly before a judge or other officer authorized by law to exercise judicial power and shall be entitled to trial within a reasonable time or to release pending trial. Release may be conditioned by guarantees to appear for trial.

4. Everyone who is deprived of his liberty by arrest or detention shall be entitled to take proceedings by which the lawfulness of his detention shall be decided speedily by a court and his release ordered if the detention is not lawful.

5. Everyone who has been the victim of arrest or detention in contravention of the provisions of this article shall have an enforceable right to compensation.

Summarizing limitations stated in the Article 5 of the ECHR it appears to be clear that, first of all, limitations must be interpreted strictly without any misinterpretations, and it shouldn't be extended the meaning of them; secondly, each of these limitations must be provided in the legislation of the country, which has to be clear enough, understandable and admissible for any person in the territory of the state, and also to be predictable. Thirdly, these limitations of the right of liberty must be applied only according the procedures, prescribed by law- in an open, public and fair hearing in front of impartial and independent judicial body, created by the power of law, and following certain rules, that guarantee the equality of procedural arms of the adversarial parties and their possibilities to represent them. Article $5(1)(c)$ governs the arrest and detention of persons for the purpose of enforcing criminal law. It serves the initiation of criminal proceedings. The power of arrest is a necessary element of the criminal justice system, but must be properly exercised in order to comply with Article 5. Today countries can only accede to the Council of Europe if they recognize the Convention, the obligatory jurisdiction of the Strasbourg Court and the right to individual petition. The Convention and its additional protocols as construed by the European Court of Human Rights - as any other fundamental rights document - has an impact on all fields of law. Legal practitioners of all kinds cannot practice law without at least basic knowledge of the provisions of the ECHR and the case law of the Court. The right of individual petition is now recognized in all member states of the Council of Europe. Petitioning the Court of Human Rights is subject to a number of admissibility criteria, most prominently the duty to exhaust all internal judicial remedies.

Criminal procedure is determined by the Constitution of the Republic of Latvia, international legal norms, and Criminal Procedure Law. Application of a criminal procedural compulsory measure has certain grounds oriented at a proper regulation of person's behaviour or action in case if performed misdemeanour is bearing an antisocial character. The above mentioned application aims resistance of a person to the reaching of the aim of criminal proceedings in concrete proceedings or to the performance

$$
\text { 00010-p.3 }
$$


of a separate procedural action, or non-execution or improper execution of his or her procedural duties. A security measure shall be applied as a procedural compulsory measure to a suspect or an accused if there are grounds for believing that the relevant person will continue criminal activities, or hinder pretrial criminal proceedings or court or avoid such proceedings and court. Criminal Procedure assumes application of various criminal procedural compulsory measures.

\section{Discussion}

Comparative analysis of the human rights in the modern and antic law provides evidence that modern human and constitutional rights, especially, in European countries is characterized by maximal differentiation, often has an individual approach, are oriented on the principles of liberty, equality, justice and democracy. Personalities and state interests are opposing each other in the area of interests' restriction - personality despite its own interest is always restricted comparing with state since state guides and controls the overall interest of the commune; simultaneously, state, its apparatus and clerks is restricted following the rights of human and citizen. According to McBride (2009), a member of the Scientific Committee of the European Union's Fundamental Rights Agency, the relevance of the European Convention to the interpretation and application of Codes of Criminal Procedure and comparable or related legislation arises both from provisions in the former that explicitly set out requirements with respect to the operation of the criminal justice system and from many others that give rise to a range of implicit requirements that will also need to be taken into account. The explicit requirements come primarily from the right to liberty and security in Article 5 and the right to a fair hearing in the determination of a criminal charge in Article 6; but also from the right of appeal in criminal matters, the right to compensation for wrongful conviction and the right not to be tried or punished twice in Articles 2, 3 and 4 of Protocol No. 7 respectively (McBride, 2009).

Innocence presumption principle is a norm of criminal procedural regulation scheduled by both European Convention of Human Rights (Article 6 (2)) and the 19th Article of the Latvian Criminal procedure Law. State becomes responsible of criminal procedural regulation of compulsory measures in case of innocence presumption principle. Moreover, application of compulsory measures should be guided by highly professional, motivated and law based decisions. National and international aspects of detention procedure performed in Latvia are summarized in a paper written by K. StradaRozenberga (2008). Whilst, making citation of Stefan Trechsel (2006), Professor of Criminal Law and Procedure, and a former President of the European Commission of Human Rights, regarding a nature and interpretation of detention, one can recognize complexity analyzing a meaning of "restriction of liberty" and "deprivation of liberty". Undoubtedly, human rights became a subject of very extensive studies in the area of humanitarian sciences, in general, and axiology and law, in particular (Kēnigs, 2010). Moreover, these have obtained an independent status, and in many circumstances these act as a co-joining factor tightly associated with functions operating within modern society. There is a prospective character within criminal procedural regulation itself, since a suspected person and accused have certain rights. Moreover, a basic nature of international legal norms is assumed to be homocentric, person oriented (Еникеев, Васильева, 2006).

\section{Conclusions}

In conclusion, it might be suggested that human rights determine the criminal procedural system. National criminal procedural system should include a mechanism of legal regulation of human rights and liberties. The relation between the European Convention and national law is a question of national law itself and the rules of general public international law and varies between the different member states. 


\section{Int. Conf. SOCIETY. HEALTH. WELFARE.}

A volume of rights allowed to each person in criminal procedure, and, therefore, the freedom of person's behavior should ensure activity regarding this person participation in criminal procedure.

State provides a guarantee of maximal protection along with recognition of fundamental rights and liberties. Simultaneously, taking over in protection of fundamental rights and freedoms, in general, and, in criminal procedure, in particular, the state is able to establish a restriction regarding person's behavior determining person's duties. Nevertheless, being required by protection of interests of the society and security, and, ensuring the effective application of the norms of the Criminal Law and the fair regulation of criminal legal relations, the persons rights are allowed to be restricted. Understanding of the aims of restriction of the human rights and liberties is related to the theoretical and practical aspects of the criminal procedural regulation taking into consideration their interpretation and realization. The theoretical aspects of the restriction of the human rights and liberties have certain specificity - within a civilized world these are considered to have a general humane and constitutional value. Possibility of further justification should be taken into consideration applying criminal procedural compulsory measures.

Legal norms and instruments should be used as main tools ensuring real existence and protection of human rights and liberties. That means that protection of person's interests and proper estimation of human values should be synchronized with protection of global social and state interests. Law axiology shows that deviations in evaluation due to misbalanced social and individual interests should appear under the scope of Criminal procedural Law, and using this instrument proper interpretation and estimation of real values as well as bringing into balance should be performed.

\section{References}

[1] Bahm, A. (1993) Axiology: The Science of Values. 41pp. [assessed 2013-05-01] http://books. google.lv/books?id=jqSRrmtQ_WoC\&pg=PA47\&lpg=PA47\&dq=bahm, +law+axiology\& source $=$ bl\&ots $=$ j79tHPfmBn\&sig=TLD3PIhXkriOietIr9YxBZVuM9Q\&hl=en\&sa=X\&ei= 2g7oUOzvDuuk4ATosIDIBg\&redir_esc=y\#v=onepage \&q=bahm\%2C\%20law\%20axiology\&f= false.

[2] European Convention on Human Rights http://www.echr.coe.int/ECHR/EN/Header/Basic+ Texts/The+Convention+and+additional+protocols/The+European+Convention+on+Human+ Rights/

[3] Kēnigs M. (2010) Cilvēktiesības. [Human rights]. Rīga: TNA, 109. lpp. (in Latvian)

[4] Latvijas Republikas Satversme, 15.02.1922. likums, publicēts Latvijas Vēstnesis, Nr. 43, 01.07.1993., stājas spēkā 07.11.1922

[5] McBride, J. (2009) Human rights and criminal procedure. The case law in the European Court of Human Rights. London: Council of Europe Publishing, 399 pp

[6] McGregor, S. (2011) Feature Article: Transdisciplinary Axiology: To Be or Not to Be? [assessed 2013-05-01]. http://integralleadershipreview.com/3388-transdisciplinary-axiology-tobe-or-not-to-be

[7] The Universal Declaration of Human Rights. http://www.un.org/en/documents/udhr/

[8] Trechsel, S. (2006) Assisted by Sarah Summers. Human Rights in Criminal Proceedings. 416 pp

[9] Еникеев З.Д., Васильева Е.Г. (2006) Исследование проблем правовой защиты общечеловеческих ценностей как одно из важных направлений развития отечественной уголовно-процессуальной науки [Study of legal regulation of overall human values as a primary direction in the development of national criminal procedural science.]. Под ред. А.В.Смирнова, Санкт-Петербург, 67 с. (in Russian) 
SHS Web of Conferences

\section{Proceedings from a conference}

1. Strada-Rozenberga, K. (2008) Kriminālprocesuālās aizturēšanas kā kriminālprocesuālā piespiedu lìdzekla būtība - nacionālie un starptautiskie aspekti [The essence of arrest as a criminal procedural compulsory measure - national and international aspects]. Kriminālprocesuālās aizturēšanas tiesiskums. Latvijas Policijas akadēmijas rakstu krājums. Rīga, 149.-151. lpp. (in Latvian). 